\title{
Fluid-rock interaction across the South Tibetan Detachment, Garhwal Himalaya (India): Mineralogical and geochemical evidences
}

\author{
Anubhooti Saxena ${ }^{1}$, Himanshu K Sachan ${ }^{1, *}$, \\ Pulok K Mukherjee ${ }^{1}$ and Dilip K Mukhopadhya ${ }^{2}$ \\ ${ }^{1}$ Wadia Institute of Himalayan Geology, Dehra Dun 248 001, India. \\ ${ }^{2}$ Department of Earth Sciences, Indian Institute of Technology, Roorkee, India. \\ ${ }^{*}$ Corresponding author. e-mail: hksachan@wihg.res.in
}

The Malari Leucogranite in the Garhwal Himalaya is cut across by a continental-scale normal fault system called the South Tibetan Detachment (STD). A mineralogical, geochemical and fluid inclusion study of samples from the fault zone of the Malari Granite was performed to reveal the imprints of fluid-rock interaction. Fluid inclusion assemblages observed in the alteration zone indicate the presence of $\mathrm{NaCl}$-dominated aqueous fluids with varied salinity of $6-16$ wt.\% of $\mathrm{NaCl}$ equivalent. Mineralogical changes include the alteration of feldspar to muscovite and muscovite to chlorite. This alteration took place at temperatures of $275^{\circ}-335^{\circ} \mathrm{C}$ and pressures between 1.9 and $4.2 \mathrm{kbars}$ as revealed by the application of chlorite thermometry, fluid isochores, and presence of $\mathrm{K}$-feldspar+muscovite+chlorite+quartz mineral assemblage. Geochemical mass-balance estimates predict $32 \%$ volume loss during alteration. An estimated fluid/rock ratio of 82 is based on loss of silica during alteration, and reveals presence of a moderately low amount of fluid at the time of faulting.

Results of fluid inclusion and alteration mineralogy indicate that the Malari Leucogranites were exhumed due to normal faulting along the STD and erosion from mid-crustal levels. Most of the leucogranites in the Himalayas occur along the STD and possibly a regional-scale fluid flow all along the STD might have caused similar alteration of leucogranites along this tectonic break. Regional fluid flow was probably concentrated along the STD and channelized through mesoscopic fractures, microcracks and grain boundaries.

\section{Introduction}

Deformation of continental crust is generally heterogeneous, concentrated into relatively narrow fault and shear zones. Formation of such zones is remarkably influenced by the concentrated flow of reactive fluids that produced significant chemical and mineralogical changes (Kerrich 1986; O'Hara 1988; Gillotti 1989; McCaig et al 1990; Goddard and Evans 1995; Streit and Cox 1998). McCaig
(1997) reviewed the studies of fluid flow in fault zones under different metamorphic conditions in different tectonic settings. He found that fluid flow in fault zones is highly variable in terms of:

- intensity and type of fluid-rock interaction,

- origin of fluid in the fault zones, and

- ability of fault zone to channelize the fluids.

Fluid-rock interaction and deformation in such fault zones may have important consequences for

Keywords. Fluid inclusion; alteration; chemistry; South Tibetan Detachment (STD); Garhwal Himalaya. 
reducing the crustal strength (Wintsch et al 1995; Stewart et al 2000). Cataclastic process, crystal plasticity, solution transport, reaction weakening in fault zone may partly control fluid pathways, fracturing, alteration and hydrolytic weakening (Engelder 1984; Mitra 1984; Chester and Logan 1986; Sinha et al 1986; Janecke and Evans 1988; O'Hara and Blackburn 1989; Glazner and Bartley 1991). Record of this interaction is partly preserved in microtextures, mineralogy, fluid inclusions and geochemical characteristics.

The South Tibetan Detachment (STD) is an important structural marker, which is present all along the Himalayan mountain chain from east to west (Valdiya 1980; Burg et al 1984; Burchfiel et al 1992). This fault zone separates the Tethyan Himalayan Sequence (THS) from the Greater or Central Himalayan crystalline sequence. In the last couple of decades, extensive geological, geophysical and geodetic studies have provided new insight on structure, geometry, kinematics and geodynamics of the STD (e.g., Burg et al 1984; Valdiya 1989; Pêcher and Scaillet 1989; Burchfiel et al 1992; Guillot and Le Fort 1995; Hodges et al 1996; Searle 1999; Searle and Godin 2003). In spite of all these studies, limited information is available on the STD as a fluid conduit and the fluid therein activity even though fluid-rock interaction in fault zones

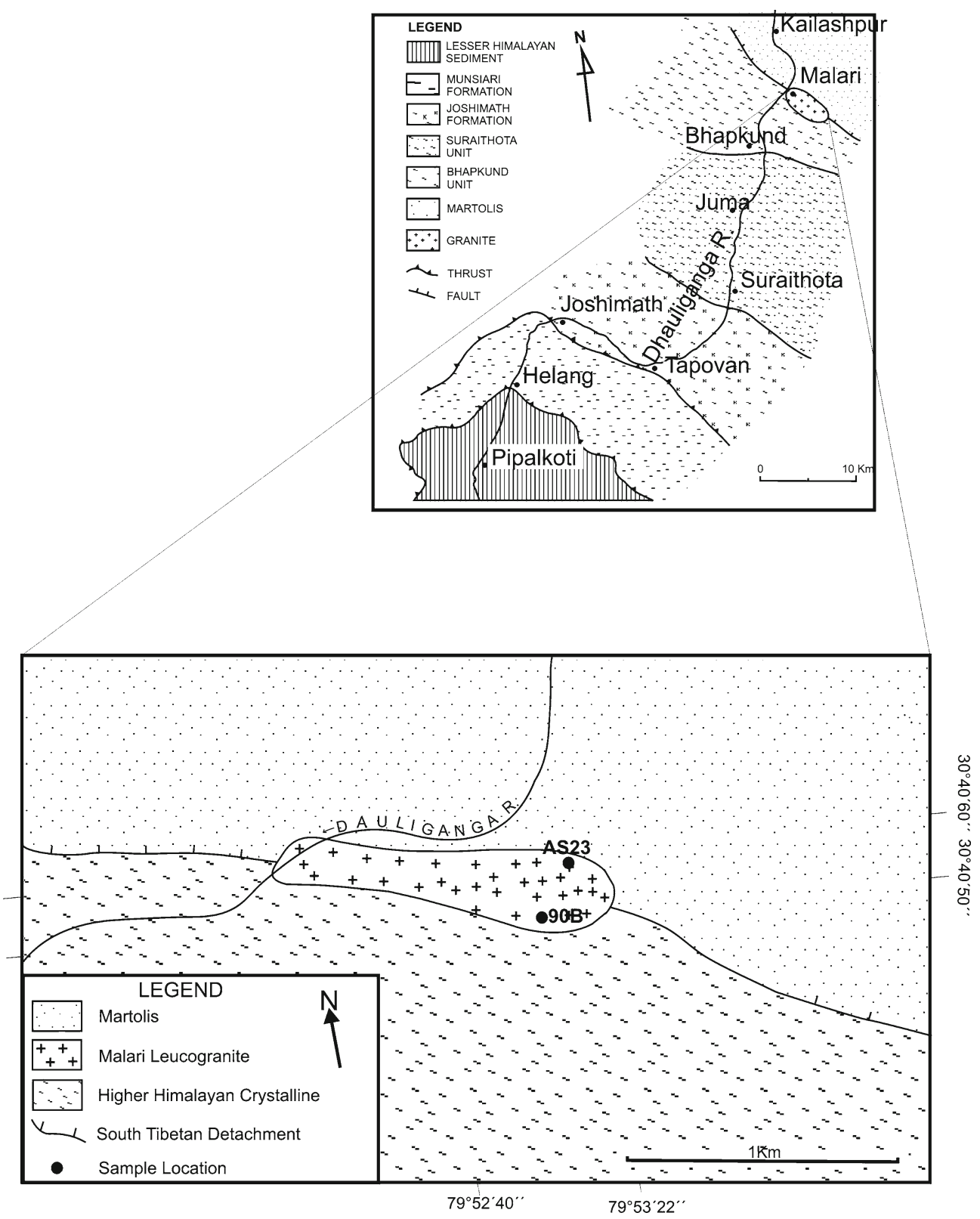

Figure 1. Geological map of the study area. Inset map shows location of Malari and lithounits exposed along the Dhauliganga valley (after Gururajan and Choudhuri 1999). 
forms an essential component in understanding the continental scale faulting (Kerrich and Kyser 1994; Evans and Chester 1995; Janssen et al 2004, 2005).

Fluids alter mineral assemblage and influences chemical and mechanical processes during deformation leading to weakening and localization of slips in fault zones (Janecke and Evans 1988; Chester et al 1993; Goddard and Evans 1995). Since fluids can leave geochemical imprints of the happenings, we have made an integrated microstructural, mineralogical, geochemical and fluid inclusion study of the STD fault in this paper to understand the processes of fluid-rock interaction along the fault zone. This study was carried out at the Malari area in Garhwal Himalaya where the STD is well-exposed and is probably the only place where the STD cuts across the Malari Leucogranite of the Himalayan orogeny.

\section{Geological setting}

The STD is well-exposed in south-central Tibet, Nepal, where it juxtaposes the unmetamorphosed, low-grade THS over the high-grade Greater Himalayan Sequence (GHS) (Burg et al 1984; Hodges et al 1996; Searle 1999). The STD is locally known as Malari Fault in the Garhwal Himalaya. Pêcher and Scaillet (1989) showed that the stretching lineation in the GHS of the Garhwal Himalaya changes systematically from being nearly perpendicular to the Himalayan range at the base to sub-parallel to the range at the top of the GHS. In the Dhauliganga river valley, contact between Tethyan sequences and the Higher Himalayan Crystalline has been marked as a fault by Roy and Valdiya (1988). This is locally named as Malari Fault, which is a part of the regional scale STDS (figure 1). Disposition of the Malari Leucogranite is quite unique and assumes its importance because it is the only leucogranite that is cross-cut by the STD in the entire length of the Himalayas from east to west (Gururajan and Choudhuri 1999). The Malari Leucogranite is approximately $1 \mathrm{~km}^{2}$, coarseto medium-grained intrusive body well-exposed around Malari village in NW Garhwal Himalaya. It intrudes into both Higher Himalayan Crystalline (Vaikrita Group) as well as Tethyan metasedimentary sequences (Martoli Formation) at $19 \pm 0.5 \mathrm{Ma}$ (Sachan et al 2010), which is estimated by U$\mathrm{Th}-\mathrm{Pb}$ geochronology of zircon from leucogranites. The high-grade sillimanite gneisses and migmatites placed under Vaikrita Group are exposed in the footwall of the STDS to the south of the leucogranite intrusive. Foliation in the gneissic rocks dips $25^{\circ}-30^{\circ}$ towards NE. The THS on the northern side of the leucogranite forms the hanging wall of the
STDS. Lithological units of the Tethyan sequence are grouped as the Martoli Formation (Valdiya 1980) and mainly consist of shale, slate and phyllite. Foliation in the Martoli rocks strikes NE-SW with a dip of $50^{\circ}-60^{\circ}$ towards NW.

\section{Analytical techniques}

Samples have been collected from outcrops of undeformed and deformed leucogranite. After detailed petrographic studies, pairs of fresh and altered leucogranite were selected for geochemical analyses and mass balance studies on the alteration of the Malari Leucogranite. Whole rock major and trace element analysis was done by X-ray fluorescence spectrometry, whereas inductive coupled plasma mass spectrometry was used for REE analysis. Back scattered electron images and mineral compositions were determined with a CAMECA SX-100 Electron Microprobe Analyzer using the following analysis conditions: acceleration voltage $15 \mathrm{KV}$, emission current $80 \mu \mathrm{A}$, beam current $20 \mathrm{nA}$, beam size $1 \mu \mathrm{m}$ and PAP correction program.

Fluid inclusions (FIs) have been investigated in doubly polished thick sections (thickness ca. $0.15 \mathrm{~mm}$ ). Measurements of phase transition temperatures in fluid inclusions were performed using a LINKAM THSMG600 heating and freezing stage with an operating range from $-196^{\circ} \mathrm{C}$ to $+600^{\circ} \mathrm{C}$ (Shepherd et al 1985), equipped with an OLYMPUS 80X ULWD objective. The stage has been calibrated at -56.6 using synthetic $\mathrm{CO}_{2}$ fluid inclusions (Bodnar and Sterner 1987). The measured temperatures have a reproducibility of \pm 0.1 to $0.2^{\circ} \mathrm{C}$ at low temperature $\left(\sim 0^{\circ} \mathrm{C}\right.$ and subzero temperature) and \pm 1 to $2^{\circ} \mathrm{C}$ at high temperatures $\left(>150^{\circ} \mathrm{C}\right)$. Compositions, densities and isochors of the fluid inclusions have been calculated using the FLINCOR program (Brown 1989) with the equations of state from Brown and Lamb (1989).

\section{Petrography}

The Malari Leucogranite are medium- to coarsegrained consisting of quartz (30-35\%), K-feldspar (35-40\%), plagioclase (15-25\%), muscovite ( $~ 5 \%)$ and tourmaline $(\sim 5 \%)$. Plagioclase is slightly zoned ranging from oligoclase $\left(\sim \mathrm{An}_{20}\right)$ in the core to albite $\left(\sim \mathrm{An}_{2}\right)$ at the rim. The unaltered granites are fresh and do not show noticeable deformation microstructures, but exhibit signs of very little alteration (partially sericitized feldspar) with typical interlocking texture (figure 2a). Myrmekitic intergrowth between quartz and plagioclase is very common in the Malari Leucogranites. Euhedral, large-zoned tourmaline crystals are frequently 

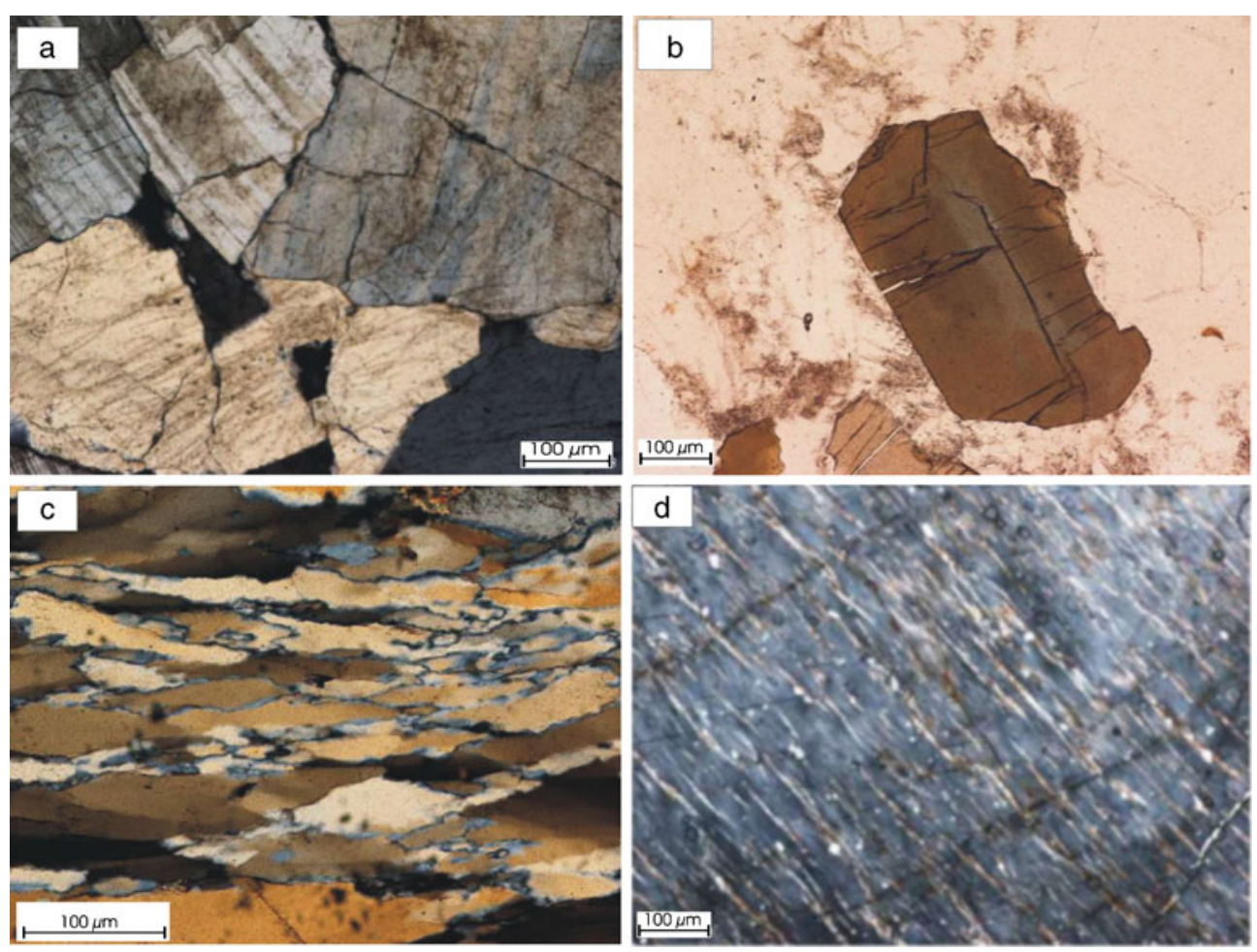

Figure 2. Petrographic features of fresh or unaltered granite. (a) Microphotographs showing interlocking texture and dominance of plagioclase feldspar, (b) large tourmaline with a bluish core and brown rims, (c) ribbon quartz in deformed granite, and (d) sericitization of feldspar.

observed, hence these leucogranites were categorized as tourmaline-leucogranites (figure 2b). Tourmaline is usually euhedral in nature, but it sometimes shows a skeletal habit in altered samples suggesting fluid-assisted partial dissolution. Tourmaline is considered as one of the most resistant minerals during deformation, but it is very sensitive to chemical alteration as we observed in the case of altered granite. It seems that tourmaline suffered partial or total replacement in the deformed rock.

In contrast, altered granites are strongly foliated and are chiefly composed of ribbon quartz, and partially altered plagioclase, microcline, orthoclase, tourmaline and muscovite (figure 2c). In addition to these primary constituents, there is hydrothermally altered secondary development of minerals such as sericite (white mica) and chlorite that define a distinct foliation plane. Sericite has replaced plagioclase and K-feldspar (figure 2d), K-feldspar forms among the largest crystals in the leucogranites and perthite growth is a characteristic feature of the leucogranite.

The textural features as shown in Back Scattered Electron (BSE) images suggest two types of muscovites. Muscovite with large well-developed cleavage and prismatic habit is probably of igneous origin (figure 3a), whereas fine-grained, fibrous muscovites (white mica) are an alteration product of K-feldspar, and hence secondary in nature. Replacement of $\mathrm{K}$-feldspar by muscovite is indicated by corroded and altered grain boundaries (figure $3 \mathrm{~b}$ ). In highly altered granite, chlorite is present as a dominant constituent. It is an obvious and established fact that chlorite in granite is normally an altered product of ferromagnesian minerals such as biotite. However, our samples do not show any traces of biotite, whereas textural and compositional details clearly indicate that muscovite is the precursor mineral of chlorite.

Study of BSE images revealed that the secondary muscovite (white mica) is further replaced or altered to chlorite, where alteration started inward from the boundary of the grain (figure 3c and $\mathrm{d}$ ). The muscovite grains also display appearance of chlorite in cracks and along kink bands with feeble pleochroism that apparently crystallized during alteration. In both cases, alteration of $\mathrm{K}$-feldspar to muscovite and subsequently to chlorite is caused by interaction of external fluid with the protolith minerals in the similar way.

Quartz grains display locally undulatory extinction, rare deformation lamellae and secondary fluid inclusion trails. K-feldspar and plagioclase grains are locally cut by intergranular microcracks that are widely spaced and sealed by quartz, mica and albite. Twin lamellae in plagioclase were displaced during deformation and alteration. Inward 

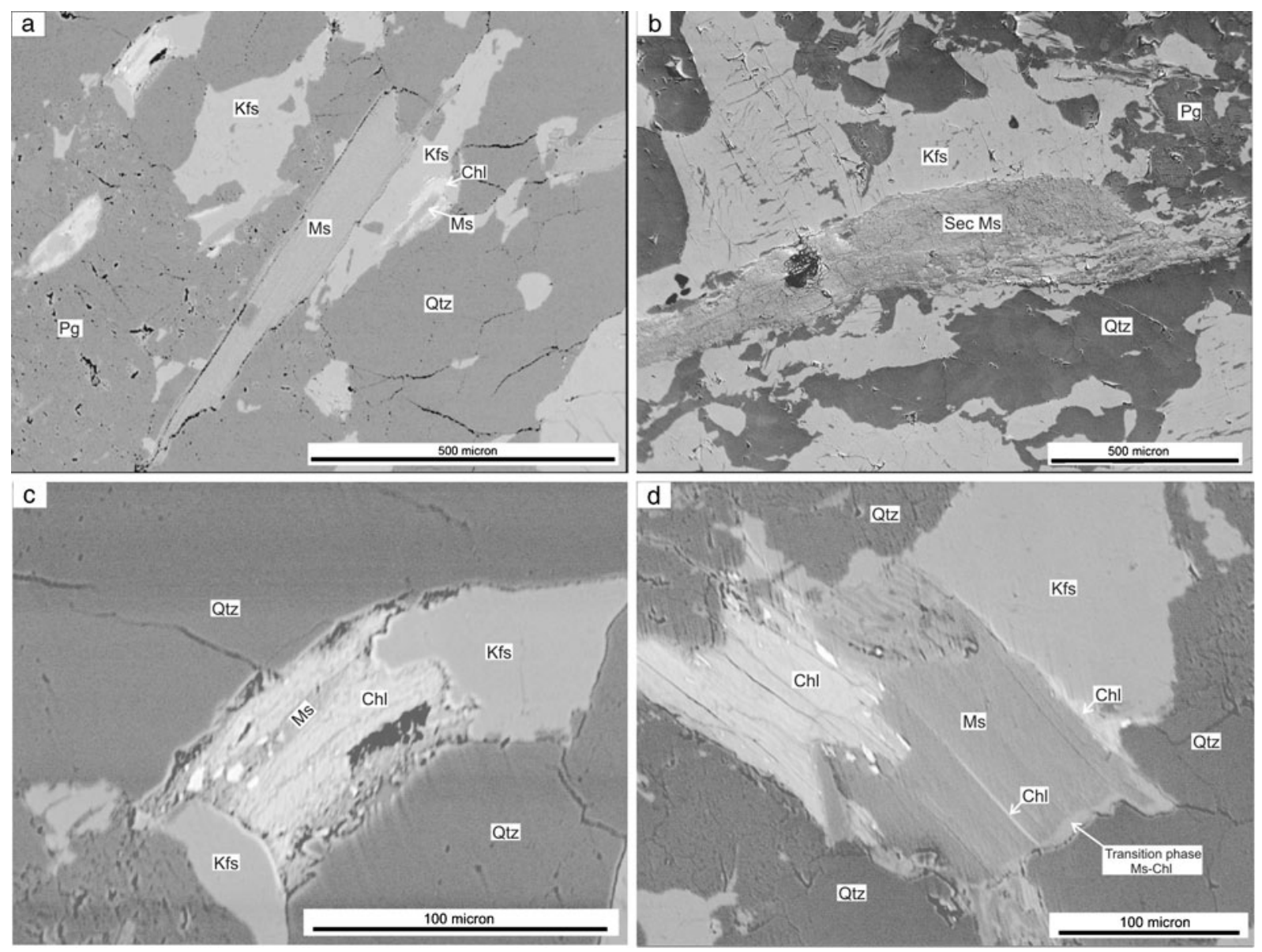

Figure 3. Back-scattered electron (BSE) images of Malari Leucogranite illustrating textural details. (a) Primary muscovite as well as the Chl-Ms transition reactions are shown in this image. (b) Secondary muscovite as a result of K-feldspar alteration during aqueous fluid activity. (c) Reaction texture of $\mathrm{Kfs}-\mathrm{Ms}-\mathrm{Chl}$ transition that shows orthoclase being altered to muscovite which then is altered to chlorite as the final product. (d) In this photomicrograph, the transition phase of $\mathrm{Ms}-\mathrm{Chl}$ is preserved at the margin of muscovite as the transition proceeds from the boundary.

local extension of cracks from grain boundaries is observed, where differential deformation of grains may have produced local stress concentration. Some microcracks are cross-cutting each other suggesting repeated episode of fluid influx, alteration, sealing and plastic deformation. The fault gauge material is dominated by foliated phyllosilicate, i.e., phyllonites.

\section{Mineral chemistry}

Representative chemical composition of the protolith mineral and their alteration product minerals are given in table 1 . Orthoclase content of the potash feldspars phenocryst in the fresh-unaltered or least-altered granite ranges between $89 \%$ and $91 \%$ (table 1). However, the K-feldspars in the deformed granites near the fault zone are almost pure orthoclase (Or >97\%) with much lower soda content compared to its undeformed counterpart. $\mathrm{Na}, \mathrm{Al}$ and $\mathrm{Ti}$ are enriched in primary (magmatic) muscovite and deficient in secondary muscovite. Additionally, secondary muscovite is also enriched in $\mathrm{Si}, \mathrm{Mg}$ and $\mathrm{Fe}$. The primary muscovite does not show evidence of zoning which indicates that muscovite of identical composition grew throughout the early crystallization history or that growth occurred at temperature capable of eliminating zoning as a result of volume diffusion (Dodson 1973).

The chlorite compositions on $\mathrm{Al}^{\text {iv }}$ versus $\mathrm{Fe} / \mathrm{Fe}+$ $\mathrm{Mg}+\mathrm{Mn}$ classification diagram (Foster 1962) revealed that most of the chlorites are $\mathrm{Fe}-\mathrm{Mg}$ rich and are identified as brunsvigite and diabantite (figure 4a). In the ternary diagram of $\mathrm{Al}-\mathrm{Fe}+\mathrm{Mg}-$ $\mathrm{Si}$, the analysed chlorites are plotted between the end members of chlorite solid-solution series, which indicates the successive enrichment from $\mathrm{Fe}-\mathrm{Mg}$ rich fluid as the alteration proceeds (figure 4b). Using chlorite geothermometer of Cathelineau and Nieva (1985), which is based on the $\mathrm{Al}^{\mathrm{iv}}$ content in chlorite, the temperature of alteration is estimated to be $275^{\circ}-315^{\circ} \mathrm{C}$. However, the cholorites in the 


\begin{tabular}{|c|c|}
\hline $\begin{array}{l}\stackrel{0}{:} \\
\stackrel{0}{0} \\
0 \\
0\end{array}$ & 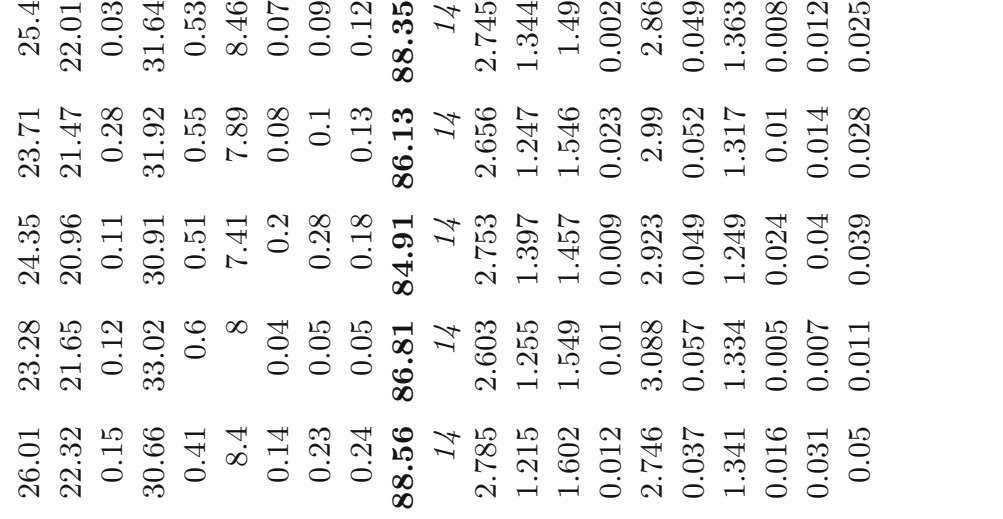 \\
\hline 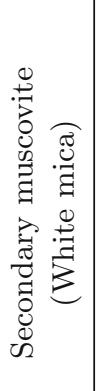 & 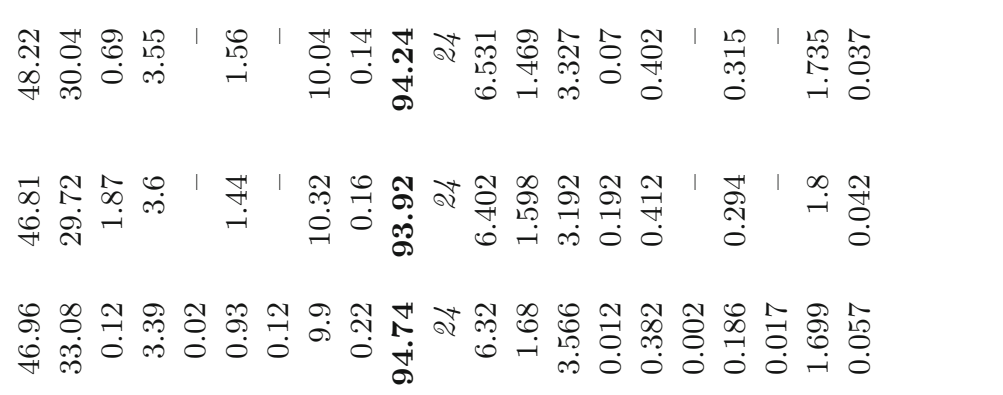 \\
\hline 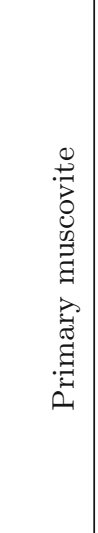 & 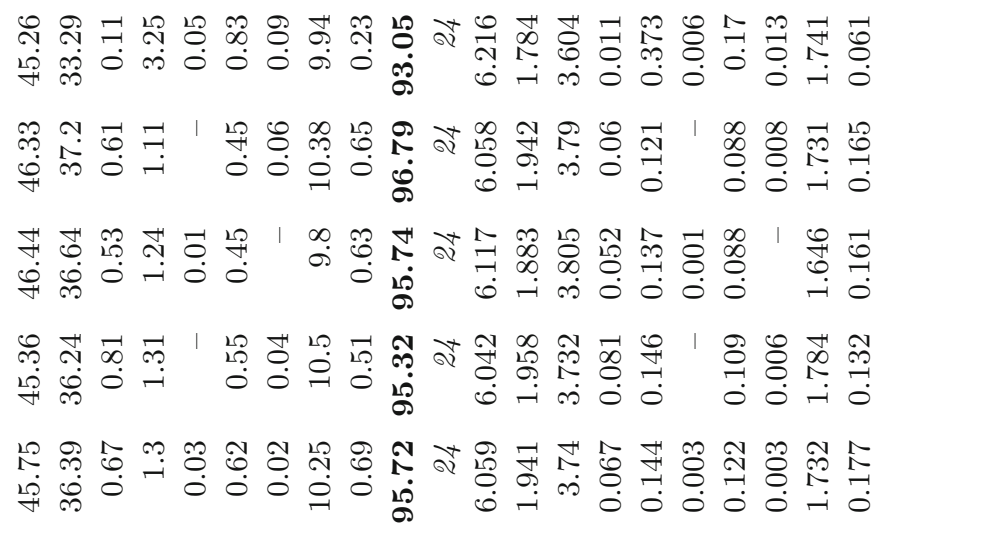 \\
\hline 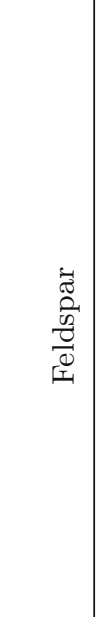 & 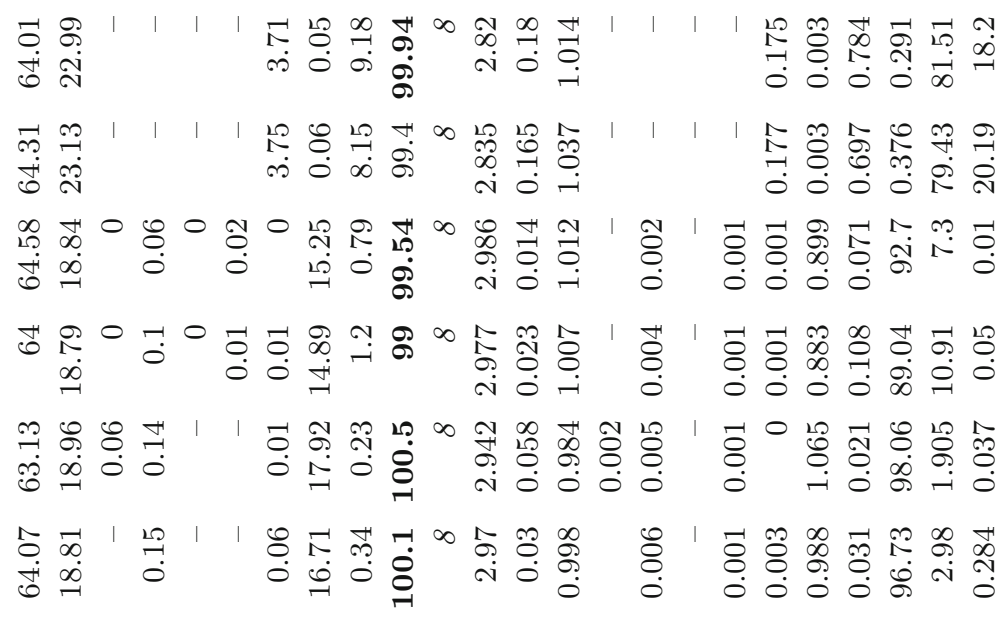 \\
\hline & 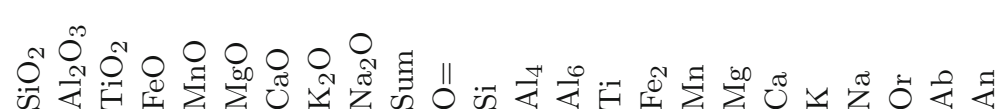 \\
\hline
\end{tabular}



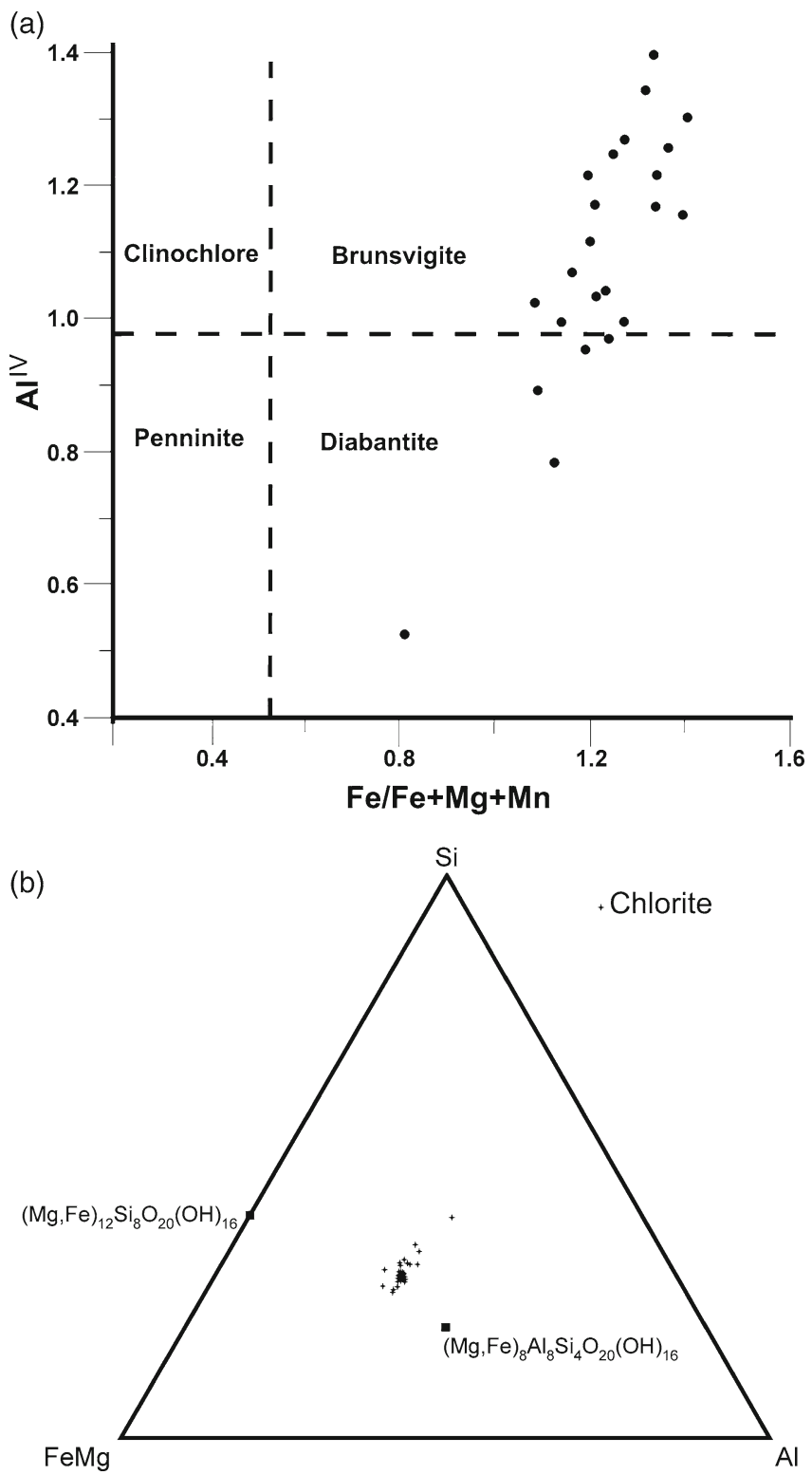

Figure 4. (a) Classification of chlorite of the Malari Leucogranite according to the scheme of Foster (1962). (b) $\mathrm{Si}-\mathrm{Fe}+\mathrm{Mg}-\mathrm{Al}$ ternary plot of chlorite compositions.

present case are sufficiently rich in Fe and $\mathrm{Mg}$ and it is more appropriate to use the thermometric equation after Vidal et al (2001, 2005) incorporating correction for $\mathrm{Fe}-\mathrm{Mg}$ exchange. Accordingly, the estimated temperatures range between $289^{\circ}$ and $320^{\circ} \mathrm{C}$ which is very close to that of Cathelineau and Nieva (1985).

\section{Fluid inclusions}

Fluid inclusions in the granite samples are predominantly secondary in nature and they provide the signature of ambient fluid trapped in minerals during the healing of microcracks. The inclusions represent an instantaneous indication of fluid composition and density during alteration. We identified two types of fluid inclusions in the studied samples. Type-A inclusions are abundant and form planar arrays in the quartz grains that crosscut the grain boundaries (figure 5a and b). These inclusions are secondary in nature as per textural criteria given by Roedder (1984), Touret (2001) and Van den Kerkhof and Hein (2001). Type-A inclusions are two-phase $(\mathrm{L}+\mathrm{V})$ and up to $10 \mu \mathrm{m}$ in their maximum size with majority of them being less than $2 \mu \mathrm{m}$ in size (figure $5 \mathrm{a}$ and $\mathrm{b}$ ) and are too small for measurements. Some inclusions show re-equilibrated features such as stretched caused by necking (figure 5c). Totally 64 inclusions were measured for final melting temperature
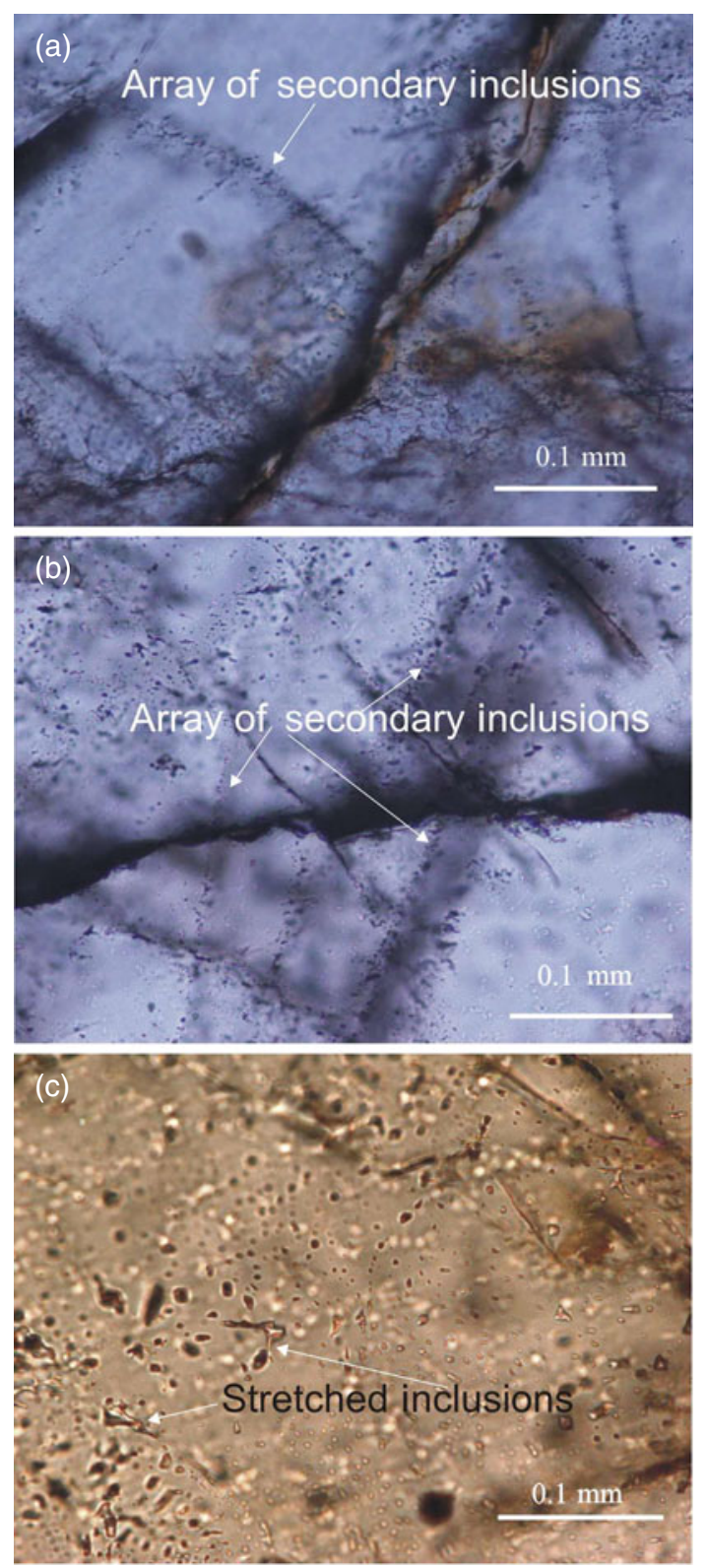

Figure 5. Microphotographs of fluid inclusions in Malari Granite. 
in which about $80 \%$ were measured for first melting temperature, while 89 inclusions were measured for homogenization temperature with 5 to $10 \mu \mathrm{m}$ size.

Type-B inclusions are two-phase $(\mathrm{L}+\mathrm{V})$ in nature and their mode of occurrence is isolated and are rarer in occurrence and do not appear to have any relationship with deformation and alteration.

The type-A fluid inclusions homogenize within the range of $125^{\circ}-190^{\circ} \mathrm{C}$ with the majority of the inclusions homogenizing from $155^{\circ}-165^{\circ} \mathrm{C}$ (figure $6 \mathrm{a})$. Their eutectic temperature range is between $-22.1^{\circ}$ and $-21.2^{\circ} \mathrm{C}$, which indicates the presence of $\mathrm{NaCl}$ as the main salt species in the solution. The final melting temperature $(\mathrm{Tfm})$ of ice ranges from $-3^{\circ}$ to $-12.5^{\circ} \mathrm{C}$ with most values between $-5.5^{\circ}$ and $-8.5^{\circ} \mathrm{C}$ (figure $6 \mathrm{~b}$ ). This corresponds to
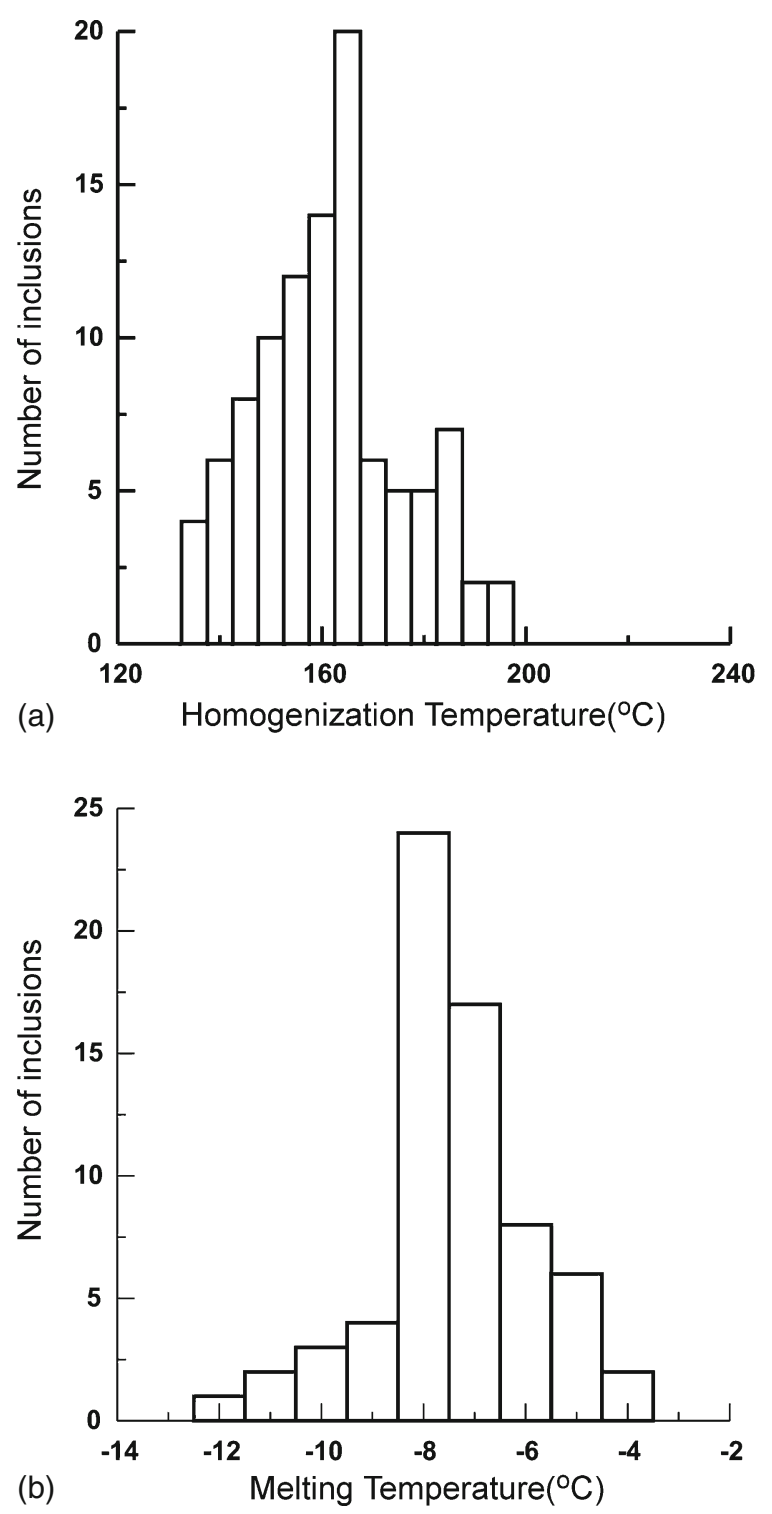

Figure 6. Histogram of final melting temperature of ice and homogenization temperature of secondary fluid inclusions from Malari Granite. a fluid salinity of 6.37 to $15.95 \mathrm{wt} \% \mathrm{NaCl}$, while their density varies between 0.97 and $0.98 \mathrm{~g} / \mathrm{cm}^{3}$.

\section{Whole rock geochemistry}

Large-scale deformation causes textural and mineralogical changes. Ubiquitous presence of aggressive fluids and accompanying grain-size reduction through crushing and grinding; are capable of mobilizing even refractory phases that contain few mobile elements. Consequently, fluid-assisted masstransfer and hence volume changes can be deciphered from the changes in major, trace and REE chemistry. Whole rock chemistry including REE data of unaltered and altered samples are presented in table 2 . In the present case, a distinct fault zone (STD) passes through the Malari Granite rendering the adjacent granitoid rock sheared and strongly deformed. Geochemical analyses of several individual samples for both altered and unaltered granites were done, only few representative ones are given in table 2 to appreciate the extent of variability. In order to assess the extent of mass-transfer that accompanied the tectonothermal deformation, a representative pair of deformed (sample no. AS/23) from the fault zone and an undeformed or least deformed fresh granitic rock (sample no. 90B) protolith was collected from the same out-crop. In view of sufficient geochemical heterogeneity of the Malari Granite (table 2), it is desirable to choose the pair that was collected in close proximity of each other at out-crop scale. Due to the inaccessibility, strong weathering and stream deposits that obliterate this narrow fault zone, not many representative sample pairs are available for geochemical mass-balance estimation that fulfils the above criteria. Although it is desirable to have several pairs to better-characterize the mass transfer with each pair being differently deformed would show the different extent of elemental mobility. The chosen pair in the present case is satisfactorily representative or at least indicative of the processes and geochemical mobility of elements involved in the alteration.

We assessed the mass-transfer that accompanies the transformation of this granite to a strongly sheared mylonitic granitic rock in the fault-zone. This is effectively done by the mass-balance equation of Gresens (1967) or a more adaptable approach after Marquer (1989) as well as of Potdevin and Marquer (1987) using immobile elements as reference frame. It is very critical to identify the immobile elements as reference frame for successful execution of mass-balance estimations. We prefer to follow the isochemical volume factor (ICVF; $\left.F_{\mathrm{v}}^{0}\right)$ approach as outlined in Mukherjee and Gupta (2008); Marquer (1989) and Potdevin and Marquer 
Table 2. Bulk-rock composition of the unaltered $(F G)$ or least and altered (AG) rocks pairs. Major element oxides are in wt\% and trace elements are in ppm.

\begin{tabular}{|c|c|c|c|c|c|c|}
\hline $\begin{array}{l}\text { Sample } \\
\text { Rock type }\end{array}$ & $\begin{array}{l}90 \mathrm{~B} \\
\text { Fresh granite }\end{array}$ & $\begin{array}{c}\text { AS } / 23 \\
\text { Altered granite }\end{array}$ & $\begin{array}{c}\mathrm{A} / 90 \\
\mathrm{FG}\end{array}$ & $\begin{array}{c}\mathrm{AS} / 25 \\
\mathrm{FG}\end{array}$ & $\begin{array}{c}\text { ML7c } \\
\text { AG }\end{array}$ & $\begin{array}{l}\mathrm{AS} 13 \\
\mathrm{AG}\end{array}$ \\
\hline $\mathrm{SiO}_{2}$ & 76.02 & 81.71 & 74.55 & 80.53 & 77.26 & 71.8 \\
\hline $\mathrm{TiO}_{2}$ & 0.11 & 0.06 & 0.04 & 0.04 & 0.12 & 0.16 \\
\hline $\mathrm{Al}_{2} \mathrm{O}_{3}$ & 14.89 & 9.75 & 15.82 & 9.86 & 14.25 & 13.85 \\
\hline $\mathrm{Fe}_{2} \mathrm{O}_{3}$ & 1.41 & 0.93 & 0.81 & 1.01 & 0.6 & 0.77 \\
\hline $\mathrm{MgO}$ & 0.03 & 0.44 & 0.02 & 0.07 & 0.03 & 0.50 \\
\hline $\mathrm{MnO}$ & 0.01 & 0.02 & 0.01 & 0.027 & 0.01 & 0.04 \\
\hline $\mathrm{CaO}$ & 0.98 & 0.02 & 0.77 & 0.22 & 0.24 & 0.39 \\
\hline $\mathrm{Na}_{2} \mathrm{O}$ & 4.75 & 2.54 & 4.60 & 5.12 & 4.16 & 3.51 \\
\hline $\mathrm{K}_{2} \mathrm{O}$ & 2.99 & 4.33 & 4.78 & 2.74 & 4.21 & 7.07 \\
\hline $\mathrm{P}_{2} \mathrm{O}_{5}$ & 0.08 & 0.043 & 0.10 & 0.095 & 0.01 & 0.19 \\
\hline LOI & 0.52 & 1.08 & 0.49 & 0.45 & 0.78 & 1.02 \\
\hline $\mathrm{Sc}$ & 31 & 3 & 27 & 1 & 48 & 3 \\
\hline $\mathrm{Ni}$ & 4.3 & 3.5 & 4.9 & 7.3 & 2 & 10 \\
\hline $\mathrm{Cu}$ & 5.2 & 7.5 & 2.1 & 9.4 & 5.4 & 22 \\
\hline $\mathrm{Zn}$ & 51.5 & 137 & 30.6 & 83.2 & 9 & 20 \\
\hline $\mathrm{Ga}$ & 25.9 & 18.2 & 21.3 & 25.2 & 18.4 & 15.9 \\
\hline $\mathrm{Pb}$ & 60 & 81.5 & 78.2 & 26.8 & 28.6 & 45.2 \\
\hline Th & 3.9 & 18.6 & 3 & 2.3 & 30.2 & 4 \\
\hline $\mathrm{Rb}$ & 156 & 380 & 241 & 250 & 225.9 & 247 \\
\hline $\mathrm{Sr}$ & 60 & 25 & 68 & 16 & 31 & 90 \\
\hline $\mathrm{Y}$ & 17.4 & 18.9 & 10 & 12 & 87.3 & 3.8 \\
\hline $\mathrm{Zr}$ & 46 & 52 & 26 & 18 & 103 & 32 \\
\hline $\mathrm{Nb}$ & 9.2 & 13.2 & 3.4 & 2 & 15.2 & 7 \\
\hline $\mathrm{La}$ & 6.39 & 13.19 & & & & \\
\hline $\mathrm{Ce}$ & 12.75 & 28.98 & & & & \\
\hline $\operatorname{Pr}$ & 1.32 & 3.35 & & & & \\
\hline $\mathrm{Nd}$ & 4.84 & 13.24 & & & & \\
\hline $\mathrm{Sm}$ & 1.34 & 3.25 & & & & \\
\hline $\mathrm{Eu}$ & 0.42 & 0.19 & & & & \\
\hline Gd & 1.24 & 2.89 & & & & \\
\hline $\mathrm{Tb}$ & 0.28 & 0.52 & & & & \\
\hline Dy & 2.10 & 3.30 & & & & \\
\hline Ho & 0.48 & 0.71 & & & & \\
\hline Er & 1.09 & 1.60 & & & & \\
\hline $\mathrm{Tm}$ & 0.15 & 0.20 & & & & \\
\hline $\mathrm{Yb}$ & 0.91 & 1.35 & & & & \\
\hline $\mathrm{Lu}$ & 0.14 & 0.20 & & & & \\
\hline Density (calculated) & 2.278 & 2.284 & & & & \\
\hline
\end{tabular}

(1987) for identification of conserved elements. The essential condition for conserved elements is that the $F_{\mathrm{v}}^{0}$ for such elements are nearly identical owing to residual enrichment or depletion (Gresens 1967). In this case, the $\operatorname{ICVF}\left(\operatorname{ICVF}=\left(C_{n}^{p} / C_{n}^{s}\right) *\left(\rho^{p} / \rho^{s}\right)=\right.$ $\left.F_{\mathrm{v}}^{0}\right)$ of each element are first calculated and rearranged in ascending order and plotted in as an ICVF variogram (figure $7 \mathrm{a}$ ). In the ICVF diagram (figure 7a), such immobile elements define flat terraces indicating cluster of elements with a tight range of ICVF values.

In the present case, it may be noted that HREEs (Dy, $\mathrm{Yb}, \mathrm{Ho}, \mathrm{Er}$ and $\mathrm{Lu}$ ) along with $\mathrm{Nb}$ and
$\mathrm{K}$ form a prominent terrace (encircled in figure $7 \mathrm{a})$ with a narrow range of ICVF values (0.670.70; shaded in table 3 ). These are mostly HFSEs having very low solubility in aqueous medium and are one of the best choices for the immobile reference frame. This is further substantiated in the chondrite normalized REE plot (figure $7 \mathrm{~b}$ ) in which, HREEs in the altered rock are enriched, but maintain parallelism with that of the precursor protolith trend (figure $7 \mathrm{~b}$ ). This suggests a simple residual enrichment of HREE abundance. However, the LREEs and MREEs do not show distinct parallelism with the protolith 


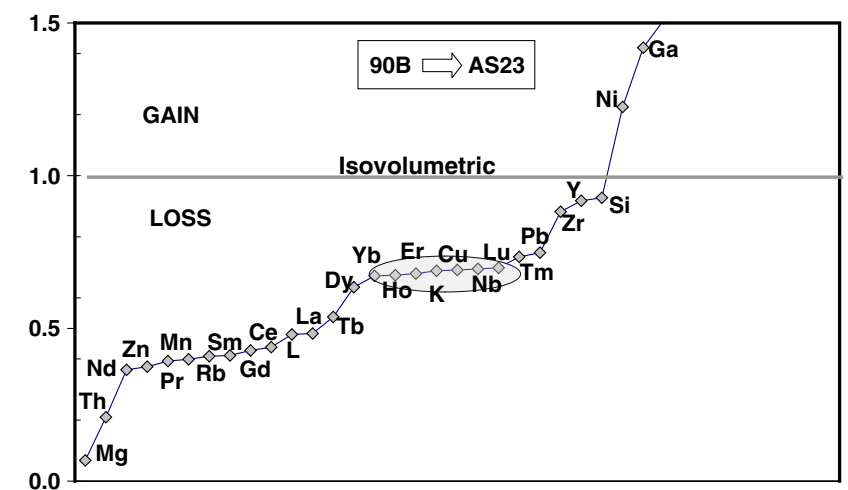

(a)

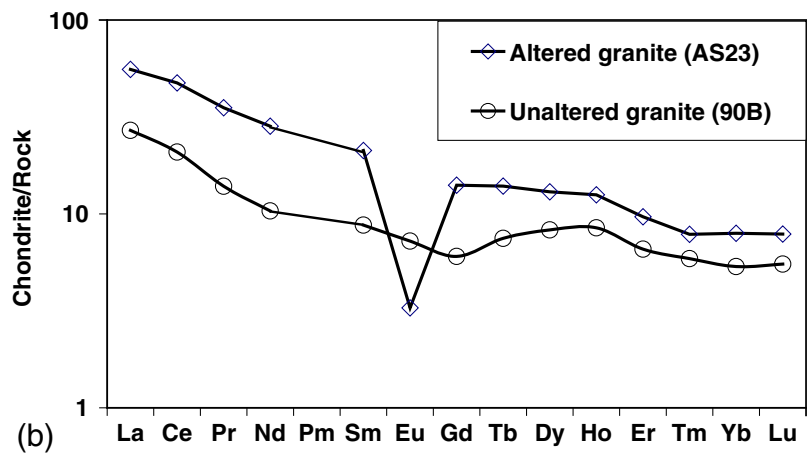

Figure 7. (a) Isochemical volume factor (ICVF) plot (Mukherjee and Gupta 2008) for the alteration of fresh granite to mylonitic granite. The cluster of elements (encircled and shaded) in the terrace with a narrow range of ICVF values are taken as immobile reference frame for the massbalance computations. Elements lying below this terrace are added and those that plot above are removed through the interacting fluid. Some elements with higher ICVF values (to the right) are not plotted for better clarity and are substantially lost in this alteration process. (b) Chondrite normalized leucogranites. HREE are more close to chondrite. Parallel trend of HREEs in mylonitic granite with respect to unaltered granite reflects residual enrichment attributable to their immobile behaviour; however, LREEs show limited mobility.

pattern, indicating their limited mobile behaviour in the present case. Although $\mathrm{Cu}$ is highly soluble its inclusion, in the list of immobile species is merely a coincidence. Moreover, the abundance of $\mathrm{Cu}(5-7 \mathrm{ppm})$ in these rocks are too low (near detection limit of X-ray fluorescence determination, i.e., 5 ppm, Saini et al 2000) and may have high uncertainty and thus excluded from further mass balance estimates. Range of volume strain is very narrow $(33 \%-30 \%)$ with respect to the above immobile elements as reference. Same inference about the conserved elements is also derived using volume composition treatment of the Marquer (1989) and Potdevin and Marquer (1987). Based on a central value of the range of ICVF (0.67-0.70, table 3) for these elements, a representative bulk volume factor of 0.685 is obtained, which corresponds to a volume loss of $31.5 \%$ for
Table 3. Isochemical volume factors (ICVF) of the elements in the alteration of granite (90B) to mylonite (AS23) arranged in ascending order. The shaded elements are the clusters of elements having identical ICVF values and considered as nearly conserved reference frame for mass-balance computations. Major elements are in the form of respective oxides. A negative value indicates loss and a positive value represent gain of the element.

\begin{tabular}{|c|c|c|c|}
\hline \multicolumn{2}{|c|}{$90 \mathrm{~B} \rightarrow \mathrm{AS} 23$} & \multicolumn{2}{|c|}{ Mass-balance } \\
\hline Ele & ICVF & Ele & Gain/loss \\
\hline \multicolumn{4}{|c|}{ Elements gained } \\
\hline $\mathrm{Mg}$ & 0.07 & $\mathrm{Mg}$ & 0.27 \\
\hline $\mathrm{Th}$ & 0.21 & Th & 8.97 \\
\hline $\mathrm{Nd}$ & 0.36 & $\mathrm{Nd}$ & 4.32 \\
\hline $\mathrm{Zn}$ & 0.37 & $\mathrm{Zn}$ & 43.30 \\
\hline $\operatorname{Pr}$ & 0.39 & $\operatorname{Pr}$ & 1.00 \\
\hline $\mathrm{Mn}$ & 0.40 & $\mathrm{Mn}$ & 0.01 \\
\hline $\mathrm{Rb}$ & 0.41 & $\mathrm{Rb}$ & 107.11 \\
\hline $\mathrm{Sm}$ & 0.41 & $\mathrm{Sm}$ & 0.91 \\
\hline Gd & 0.43 & $\mathrm{Gd}$ & 0.76 \\
\hline $\mathrm{Ce}$ & 0.44 & $\mathrm{Ce}$ & 7.30 \\
\hline LOI & 0.48 & LOI & 0.23 \\
\hline $\mathrm{La}$ & 0.48 & $\mathrm{La}$ & 2.74 \\
\hline $\mathrm{Tb}$ & 0.54 & $\mathrm{~Tb}$ & 0.08 \\
\hline Dy & 0.63 & Dy & 0.18 \\
\hline \multicolumn{4}{|c|}{ Minimum mobility or conserved } \\
\hline $\mathrm{Yb}$ & 0.67 & $\mathrm{Yb}$ & 0.02 \\
\hline Ho & 0.67 & Ho & 0.01 \\
\hline $\mathrm{Er}$ & 0.68 & $\mathrm{Er}$ & 0.02 \\
\hline $\mathrm{K}$ & 0.69 & $\mathrm{~K}$ & 0.01 \\
\hline $\mathrm{Cu}$ & 0.69 & $\mathrm{Cu}$ & -0.01 \\
\hline $\mathrm{Nb}$ & 0.69 & $\mathrm{Nb}$ & -0.07 \\
\hline $\mathrm{Lu}$ & 0.70 & $\mathrm{Lu}$ & 0.00 \\
\hline \multicolumn{4}{|c|}{ Elements lost } \\
\hline $\mathrm{Pb}$ & 0.73 & $\mathrm{~Pb}$ & -3.61 \\
\hline $\operatorname{Tm}$ & 0.75 & $\operatorname{Tm}$ & -0.01 \\
\hline $\mathrm{Zr}$ & 0.88 & $\mathrm{Zr}$ & -10.02 \\
\hline $\mathrm{Y}$ & 0.92 & $\mathrm{Y}$ & -4.32 \\
\hline $\mathrm{Si}$ & 0.93 & $\mathrm{Si}$ & -19.48 \\
\hline $\mathrm{Ni}$ & 1.23 & $\mathrm{Ni}$ & -1.88 \\
\hline $\mathrm{Ga}$ & 1.42 & $\mathrm{Ga}$ & -13.31 \\
\hline $\mathrm{Fe}$ & 1.51 & $\mathrm{Fe}$ & -0.77 \\
\hline $\mathrm{Al}$ & 1.52 & $\mathrm{Al}$ & -8.14 \\
\hline $\mathrm{Ti}$ & 1.83 & $\mathrm{Ti}$ & -0.07 \\
\hline $\mathrm{P}$ & 1.86 & $\mathrm{P}$ & -0.05 \\
\hline $\mathrm{Na}$ & 1.86 & $\mathrm{Na}$ & -2.99 \\
\hline $\mathrm{Eu}$ & 2.20 & $\mathrm{Eu}$ & -0.29 \\
\hline $\mathrm{Sr}$ & 2.39 & $\mathrm{Sr}$ & -42.70 \\
\hline $\mathrm{Sc}$ & 10.30 & $\mathrm{Sc}$ & -28.92 \\
\hline $\mathrm{Ca}$ & 48.86 & $\mathrm{Ca}$ & -0.97 \\
\hline
\end{tabular}

the shearing process under consideration. Following the Gresens' (1967) mass-balance equation, the relative mass-transfers for all elements was computed by using 0.685 as the bulk volume factor. The results of the mass-balance are summarized in table 3. The mass-balance results for major 
elements are given in grams per 100 grams of the protolith and that of trace elements are in parts per million parts of protolith (table 3 ).

\section{Discussion}

\subsection{Geothermobarometry}

The $P-T$ conditions of alteration are estimated on the basis of alteration mineralogy and fluid inclusions. The biphase aqueous inclusions in the fault zone can be used to place constraints on the $P-T$ history of the rocks. Isochores for the biphase aqueous inclusions were estimated using the 'FLINCOR' program (Brown 1989) and the equation of state by Zhang and Frantz (1987). Isochores derived from isolated inclusions in our samples indicate a higher pressure of formation compared to inclusions that occur along fractures (figure 8). This reflects the greater tendency for fracture hosted inclusions to re-equilibrate, compared to isolated inclusions in the cores of mineral grains (Bodnar 2003).

The $P-T$ stability fields of these minerals are shown along with the fluid inclusion isochores in figure 8 . The area where the fluid inclusion isochores and the stability fields overlap defines a $P-T$ region that extends from $273^{\circ} \mathrm{C}$ and $1.8 \mathrm{kbars}$ to about $335^{\circ} \mathrm{C}$ and about $2.8-4.2$ kbar. The upper limit of this temperature range (figure 8 ) is marginally higher than the temperatures of estimated using chlorite geothermometry, i.e., $312^{\circ} \mathrm{C}$. The range in homogenization temperatures within an individual mineral grain and along an individual fracture suggests that the inclusions have either 'stretched' or 'contracted' in response to the changing $P-T$ conditions during emplacement and exhumation. The main effect of volumetric reequilibration of fluid inclusions is to shift the isochores to lower pressures (stretching) or higher pressures (contraction) for a given temperature, and examples of both processes have been documented in the literature (Vityk et al 1995, 1996). The fluid inclusions in the Malari Granite would have re-equilibrated by stretching to produce lower densities (figure 5c). However, the higher-pressure isochors shown in figure 8 would correspond closest to the original formation conditions, whereas the lower pressure isochores would reflect conditions of exhumation. The $P-T$ path undergone by the Malari Granite in the fault zone passed through the shaded region during the alteration process (figure 8).

The range in isochors is consistent with the pressure of 1.8 to $4.2 \mathrm{kbar}$, which in turn corresponds to a minimum and maximum depth of 4 to $12 \mathrm{~km}$ for the study area. Deformation and metamorphism may have produced a thermal regime that initiated fluid flow by metamorphic dewatering and deep circulation of meteoric or formation water. We estimate a maximum depth of $12 \mathrm{~km}$ in the fault zone of STD for the source of fluids and initiation of alteration processes. This type of deep circulation of fluids is possible in an episodic manner during earthquakes (Sibson 1992; Byerlee 1993), known as fault-valve mechanism, which facilitate more fluid pressure along the STD similar to the findings of McCaig (1988) for the Pyrenees fault zone. A seismic pumping or faultvalve is an important mechanism for large-scale fluid flow in active faulting with lithostaticpressured layers and suprahydrous vertical gradient in fluid pressure conditions. The pulsating action of valving depends upon the ability of faults to behave as seals when they are tectonically quiescent and as conduits during and immediately following rupturing. Presence of fault cataclastic gauge materials consisting of fine-grained clays and mineral precipitates within the fault core acts as sealant during the inter-seismic period. Breaching of this barrier to over-pressured zones by co-seismic rupturing facilitates easy fluid flow (Sibson 1992; Nemcok et al 2009). The depth of emplacement of the Mansalu Leucogranite in the Nepal Himalaya is of 9 to $13 \mathrm{~km}$ which is occurring under similar condition along the STD (Guillot and Le Fort 1995; Searle and Godin 2003) and is very similar to the depth of alteration estimated for the Malari Leucogranite.

\subsection{Reaction softening}

The concentration of deformation into fault zones is generally associated with strain softening of the zone relatively to the surrounding wall rock (White et al 1980). The possible softening mechanisms include reaction softening, grain size reduction and hydrolytic weakening of quartz (Kronenberg et al 1984; Mitra 1984; Wintsch et al 1995). Alteration of minerals resulted in the conversion of feldspar minerals to muscovite and subsequently to chlorite and quartz. Feldspar is expected to remain relatively resistant in comparison to mica at the time of deformation (Janecke and Evans 1988). Growth of fine-grained, initially dislocation-free mica and quartz occur during both mass-transfer and plastic deformation. This phenomenon is well-illustrated in the BSE images of micas, which documents the transformation of muscovite to chlorite. Such lamellae of muscovite initially start transforming itself into chlorite and subsequently the whole grain is transformed to chlorite (figure $3 \mathrm{c}$ and d).

Secondary muscovite (white mica) is compositionally different from primary (magmatic) muscovite. The former muscovite was produced due 


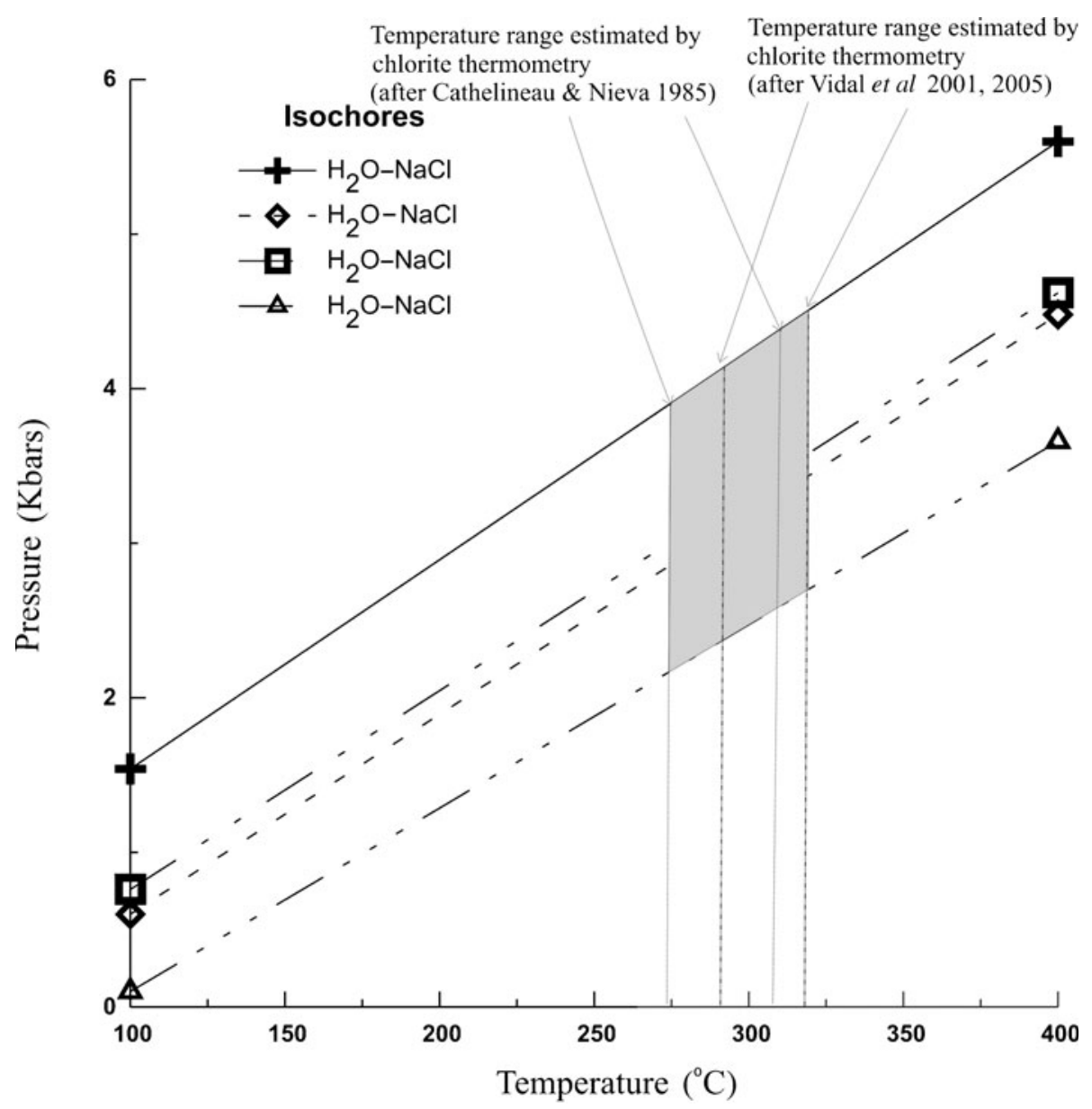

Figure 8. Isochores for the mode and range of homogenization temperatures and average salinities are indicated in a $\mathrm{P}-\mathrm{T}$ diagram. The isochores intersect temperatures estimated from chlorite geothermometry (dash-dot lines). The shaded area is showing $P-T$ condition for the alteration of the Malari Granite.

to interaction of fluid with granitic rock. Fluidinduced alteration of $\mathrm{K}$-feldspar to muscovite took place by the following balanced reaction derived from the average mineral compositions (table 2).

$$
\begin{aligned}
& \text { K-feldspar } \rightarrow \text { muscovite } \\
& \quad 2528.1553 \mathrm{Kfs}+1273.3942 \mathrm{H}_{2} \mathrm{O}+1.0000 \mathrm{Mn} \\
& \quad+55.8874 \mathrm{Fe}+53.4718 \mathrm{Mg}+1.0000 \mathrm{Ca} \\
& \quad+30.0000 \mathrm{Ti} \rightarrow 1000.0000 \mathrm{Ms}+4749.3184 \mathrm{Qtz} \\
& \quad+1438.3612 \mathrm{~K}+192.0408 \mathrm{Na}+546.7883 \mathrm{H}
\end{aligned}
$$

This suggests that the alteration of K-feldspar took place during a large influx of meteoric fluid that leads to the volume reduction and simultaneous increase in porosity and permeability. This change in physical properties leads to further infiltration of fluid (Rumble and Spear 1983) and negative change in volume also acts as a catalytic agent to speed up the alteration of K-feldspar to muscovite (Simpson and Wintsch 1989).
Alteration of muscovite to chlorite started in a similar fashion to the alteration of K-feldspar to muscovite (figure 3c). The alteration of muscovite to chlorite took place by the following balanced reaction using average compositions of pertinent muscovite and chlorite (table 2).

$$
\begin{aligned}
& \text { Muscovite } \rightarrow \text { chlorite } \\
& \begin{array}{l}
107.0272 \mathrm{Ms}+129.9600 \mathrm{Qtz}+1216.6660 \mathrm{H}_{2} \mathrm{O} \\
\quad+5.5682 \mathrm{Mn}+414.1286 \mathrm{Fe}+199.6944 \mathrm{Mg} \\
\quad+2.3471 \mathrm{Ca} \rightarrow 153.3840 \mathrm{Chl}+80.2247 \mathrm{~K} \\
\quad+1.0000 \mathrm{Na}+1.3702 \mathrm{Ti}+1420.3143 \mathrm{H}^{+}
\end{array}
\end{aligned}
$$

It is interesting to note that $\mathrm{Fe}$ and $\mathrm{Mg}$ are required for both reactions (equations 1 and 2) to proceed, whereas substantial amount of $\mathrm{K}$ is released into the fluid phase. Due to the absence of any major Mg-bearing phase in the protolith, the $\mathrm{Mg}$ is probably provided externally through the interacting fluid. However, Fe was probably made available 
internally through the oxidation of $\mathrm{Fe}-\mathrm{Ti}$ oxides minerals with the excess Fe, if any, is removed through the fluid. In the above two reactions, $\mathrm{K}$ is released into the fluid, which contributed to the re-crystallization of $\mathrm{K}$-feldspars and mica in the groundmass. Moreover, mineral chemistry data reveal that $\mathrm{K}$-feldspars in altered granite are more potash-rich and that plagioclase is relatively enriched in Na-rich compared to fresh granite. Consequently, part of the $\mathrm{K}$ released has been used up in K-metasomatism of K-feldspar phenocrysts as well as in the crystallization of neoform K-feldspar in the groundmass.

\subsection{Geochemical mass balance}

Fluid influx produced a complex intergranular and grain boundary network with varying amounts of quartz-mica (muscovite-chlorite) rich matrix due to alteration of feldspar (figure 2d). Such alteration of feldspar to mica resulted in local volume loss that may transiently increase grain-scale porosity and permeability. Grain-size reduction due to alteration and recrystallization increased the surface density of grain boundaries that potentially leads to increased permeability as documented for many fault zones (e.g., Géraud et al 1995). Such dynamothermal alteration, where cataclasis becomes an important mechanism of grain-size reduction; facilitates easy fluid channeling and better opportunity of dissolution and hence enhanced elemental mobility (O'Hara 1988). In order to substantiate petrographic observation and fully understand the process, it is essential to quantify the mass transfer. Deformation-induced elemental exchange between protolith rock and the interacting fluid is best appreciated through geochemical massbalance. The major element mass-balance computation predicts the following equation for the alteration process (see table 3 ).

$$
\begin{aligned}
& 100 \mathrm{~g} \text { Fresh Granite }+0.27 \mathrm{~g} \mathrm{MgO}+0.01 \mathrm{~g} \mathrm{MnO} \\
& \quad+0.23 \mathrm{~g} \mathrm{H}_{2} \mathrm{O}=67.82 \mathrm{~g} \text { Altered Granite } \\
& \quad+19.48 \mathrm{~g} \mathrm{SiO}_{2}+8.14 \mathrm{~g} \mathrm{Al}_{2} \mathrm{O}_{3}+2.99 \mathrm{~g} \mathrm{Na}_{2} \mathrm{O} \\
& +0.97 \mathrm{~g} \mathrm{CaO}+0.77 \mathrm{~g} \mathrm{Fe}_{2} \mathrm{O}_{3}+0.07 \mathrm{~g} \mathrm{TiO}_{2} \\
& +0.05 \mathrm{~g} \mathrm{P}_{2} \mathrm{O}_{5}
\end{aligned}
$$

Out of the total mass loss, $\mathrm{SiO}_{2}$ alone accounts for two-thirds of the loss (20.5 g), while the remaining $1 / 3$ is due to loss of $\mathrm{Al}_{2} \mathrm{O}_{3}$ (8.14 g), $\mathrm{Na}_{2} \mathrm{O}$ (2.99 g) and $\mathrm{CaO}(0.97 \mathrm{~g})$. Sizeable loss of silica can only be explained by dissolution of quartz and that of $\mathrm{Al}$, $\mathrm{Na}$ and $\mathrm{Ca}$ is consistent with dissolution of plagioclase. Though, K-feldspars is also affected by the alteration, the released $\mathrm{K}_{2} \mathrm{O}$ is partly buffered by the precipitation of white mica (sericite and muscovite) and re-crystallized groundmass K-feldspar coupled with potash metasomatism of phenocrystic $\mathrm{K}$-feldspars rendering $\mathrm{K}_{2} \mathrm{O}$ conserved in the process. Calcium content of fresh granite is almost exhausted in the altered rock and hence existence of plagioclase especially, anorthitic plagioclase in the altered rock is rather infrequent. Plagioclase dissolution would also release ample amounts of $\mathrm{Na}$ into the fluid. Comparing the above geochemical mass-balance equation (equation 3 ) and the balanced reaction (equations 1 and 2), we infer that the requirement of the ferro-magnesian component $(\mathrm{Mg}, \mathrm{Mn} \mathrm{Fe}, \mathrm{Ti})$ for chlorite precipitation is met externally, whereas the Ca requirement was fulfilled internally by the breakdown of K-feldspars and plagioclase.

Similar to the major elements, the selective removal of $\mathrm{Eu}$ and $\mathrm{Sr}$ in noticeable proportion is also consistent with disappearance of plagioclase. This is also discernable from the REE patterns where a large negative Eu anomaly (figure $7 \mathrm{~b}$ ) is produced predicting loss of Eu through dissolution of plagioclase. REEs are generally considered less mobile but limited mobility of REEs have been widely reported by several workers under aggressive tectonothermal conditions such as shear zones, where mechanical crushing takes place under elevated temperature in the presence of large amounts of fluids (Vocke et al 1987; Grauch 1989; Wayne and Sinha 1988, 1992; Lottermoser 1992; Pan and Fleet 1995; Förster 2000; Rolland et al 2003; Essaifi et al 2004). Over $90 \%$ of the REE budget in a granitic rock is accounted for by accessory phases (e.g., LREEs in monazite, HREEs in zircon and MREEs in apatite). Depending upon the dissolution or re-precipitation of one or more of these phases, the slope of the REE trend would be disturbed. In view of immobility of HREEs, it is inferred that monazite and apatite might have undergone chemical modification, but zircons remained largely unaffected. An increased abundance in the altered rock is consequently due to residual enrichment because of the loss of other elements (e.g., $\mathrm{SiO}_{2}, \mathrm{Al}_{2} \mathrm{O}_{3}$ and $\mathrm{CaO}$ ). On the other hand, LREEs show enrichment that is in excess of expected residual enrichment and are added to the system by the interacting fluid.

\subsection{Fluid-rock ratio}

Hydrothermal alterations invariably involve the release of silica as a result of its high solubility in aqueous solutions that brings about net volume loss and attendant mineralogical changes. This loss in silica has also been effectively used for the estimation of fluid-rock ratio (Sinha et al 1986; O'Hara 1988; Selverstone et al 1991; Newman and Mitra 1993; Goddard and Evance 1995; Barnes et al 2004). The solubility of silica at appropriate 
$P-T$ condition is sufficiently studied in hydrothermal system and modelled at a wide range of $P-T$ conditions (Fournier and Potter 1982). Solubility of silica calculated from this model is $0.3 \mathrm{~g}$ per $100 \mathrm{~g}$ of solvent at an average temperature of $335^{\circ} \mathrm{C}$ and a pressure of $4 \mathrm{kbar}$ as indicated from the fluid inclusion thermobarometry. Considering this value for solubility of silica, the amount of fluid required to remove $19.5 \mathrm{~g}$ of silica from $100 \mathrm{~g}$ of the protolith, is estimated to be about 65 times the amount of rock affected. However, the interacting fluid is never pristine in nature; it may already be partially saturated. This implies that the fluid/rock ratio could have been greater than 65 depending upon the prior saturation with respect to silica. The low saline nature of the secondary fluid inclusions suggests that the interacting hydrothermal fluid was not highly saturated with respect to silica a priori. We, therefore, calculated the fluid/rock ratio assuming that the hydrothermal solution was $20 \%$ saturated in silica. Accordingly, the fluid/rock ratio is calculated to be 82 , which suggests the presence of moderately high fluid during the faulting causing strong reaction softening of the leucogranite. The Malari Leucogranites have been uplifted from a midcrustal level as shown by fluid inclusions and alteration mineralogy along the STD. As most of the leucogranites in the Himalayas are occurring along the STD; it might be possible that the same type of alteration might be developed due to regional fluid flow.

\section{Conclusions}

The Malari Leucogranite has suffered strong episodes of shear-induced fracturing, fluid influxes, and alteration resulted in progressive conversion of coarse-grained leucogranite into fine-grained altered granite by cataclasis and external fluid rock interaction led to material transfer that resulted in significant changes in mineral chemistry, material transfer and mineral abundances. Fluid inclusion study aided by mineral equilibrium estimations points that alteration of feldspar to muscovite and further from muscovite to chlorite took place at a maximum depth of $12 \mathrm{~km}$ and temperature range of $275^{\circ}$ to $350^{\circ} \mathrm{C}$ along the STD. Whole rock geochemistry and mass-transfer estimates suggest a bulk volume loss of $31.5 \%$ during faulting with respect to immobility of HREEs, $\mathrm{K}$ and $\mathrm{Nb}$ as reference frame. There was also suggestion of substantial dissolution of quartz. Decomposition of plagioclase and K-feldspar and appearance of muscovite and chlorite are inferred as operative mechanisms to explain the observed mineralogical and geochemical changes in the Malari Leucogranite in response to the normal faulting of STD in presence of moderate fluid (fluid/rock $=82$ ) sourced from deeper (metamorphic) circulations. The observation of fluid origination from deep sources and regional fluid-flow was probably concentrated along the STD through mesoscopic fractures, microcracks and grain boundaries by the mechanism of seismic pumping.

\section{Acknowledgements}

Authors are grateful to the Director of the Wadia Institute of Himalayan Geology, Dehradun for providing necessary facilities to carry out this work and kind permission to publish the paper.

\section{References}

Barnes J D, Selverstone J and Sharp Z D 2004 Interaction between serpentinite devolatilization, metasomatism and strike-slip strain localization during deep-crustal shearing in Eastern Alps; J. Metamorph. Geol. 22 283-300.

Bodnar R J 2003 Reequilibration of fluid inclusions; In: Fluid Inclusions: Analysis and Interpretation (eds) Samson I, Anderson A and Marshall D, Mineral. Assoc. Canada 32 213-230.

Bodnar R J and Sterner S M 1987 Synthetic fluid inclusion; In: Hydrothermal Experimental Techniques (eds) Barnes H L and Ulmer G C (New York: Wiley), pp. 423-457.

Brown P E 1989 FLINCOR: A microcomputer program for the reduction and investigation of fluid inclusion data; Amer. Mineral. 74 1390-1393.

Brown P E and Lamb W M 1989 PVT properties of the fluids in the system $\mathrm{H}_{2} \mathrm{O}-\mathrm{CO}_{2}-\mathrm{NaCl}$ : New graphical presentation and implication of fluid inclusion studies; Geochim. Cosmochim. Acta 53 1209-1221.

Burchfiel B C, Zhiliang C, Hodges K V, Yuping L, Royden L H, Changrong D and Jiene X 1992 The South Tibetan Detachment System, Himalayan Orogen; Geol. Soc. Am. Spec. Paper 269 1-41.

Burg J P, Brunel M, Gapais D, Chen G M and Liu H 1984 Deformation of leucogranites of the crystalline main central sheet in southern Tibet (China); J. Struct. Geol. 6 535-542.

Byerlee J 1993 Model for episodic flow of high-pressure water in fault zones before earthquake; Geology 21 303-306.

Cathelineau M and Nieva D 1985 A chlorite solid solution geothermometer: The Los Azufres (Mexico) geothermal system; Contrib. Mineral. Petrol. 91 235-244.

Chester F M and Logan J M 1986 Implications for mechanical properties of brittle faults from observations of the Punchbowl fault zone, California; Pure Appl. Geophys. $124 \mathrm{~W}-106$.

Chester F M, Evans J P and Biegel R L 1993 Internal structure and weakening mechanism of faults of San Andreas Fault system; J. Geophys. Res. 98 771-786.

Dodson M H 1973 Closur temperatures in cooling geochronological and petrological systems; Contrib. Mineral. Petrol. $109526-537$.

Engelder T 1984 The role of pore water circulation during the deformation of foreland folds and thrust belts; J. Geophys. Res. 89 4319-4325.

Essaifi A, Capdevila R, Fourcade S, Lagarde J L, Ballèvre M and Marignac C H 2004 Hydrothermal alteration, fluid flow and volume change in shear zones: The layered 
mafic-ultramafic Kettara intrusion (Jebilet Massif, Variscan belt, Morocco); J. Metamorph. Geol. 22 25-43.

Evans J P and Chester F M 1995 Fluid-rock interaction in faults of the San Andreas System: Inferences from San Gabriel fault rock geochemistry and microstructures; J. Geophys. Res. 100 13,007-13,020.

Foster M D 1962 Interpretation of the composition and classification of chlorites; US Geol. Surv. Prof. Paper 414A 27.

Förster H-J 2000 Cerite-(Ce) and Thorite Synchysite-(Ce) from the Niederbobritzsch granite, Erzgebirge, Germany: Implication for the differential mobility of the LREE and Th during alteration; The Canadian Mineralogist $\mathbf{3 8}$ 67-79.

Fournier R O and Potter R W II 1982 An equation correlating the solubility of quartz in water from 250 to $900^{\circ} \mathrm{C}$ at pressure up to 10,000 bars; Geochem. Cosmochim. Acta 46 1969-1973.

Géraud Y, Caron J and Faure P 1995 Porosity network of a ductile shear zone; J. Struct. Geol. 17 1757-1769.

Gilotti J A 1989 Reaction progress during mylonitization of basaltic dikes along the Sarv thrust, Swedish Caledonides; Contrib. Mineral. Petrol. 101 30-45.

Glazner A F and Bartiey J M 1991 Volume loss, fluid flow and state of strain in extensional mylonites from the central Mojave Desert, California; J. Struct. Geol. 13 $587-594$.

Goddard J V and Evans J P 1995 Chemical changes and fluid-rock interaction in faults of crystalline thrust sheets, northwestern Wyoming, U.S.A.; J. Struct. Geol. 17 $533-547$.

Grant J A 1986 The Isocon diagram - A simple solution to Gresen's equation for metasomatic alteration; Economic Geology 81 1976-1982.

Grauch R I 1989 Rare earth elements in metamorphic rocks; In: Geochemistry and mineralogy of rare earth elements (eds) B L Lupin and G A McKay, Rev. Mineral. 21 147-167.

Gresens P L 1967 Composition-volume relationships of metasomatism; Chem. Geol. 2 47-65.

Guillot S and Le Fort P 1995 Geochemical constraints on the bimodal origin of High Himalayan leucogranites; Lithos 35 221-234.

Gururajan N S and Choudhuri B K 1999 Ductile thrusting, metamorphism and normal faulting in Dhauliganga valley, Garhwal Himalaya; Himalayan Geol. 20 19-29.

Hodges K V, Parrish R R and Searle M P 1996 Tectonic evolution of the central Annapurna Range, Nepalese Himalayas; Tectonics 15 1264-1291.

Janecke S U and Evans J P 1988 Feldspar-influenced rock rheologies; Geology 16 1064-1067.

Janssen C, Romer R L, Hoffmann-Rothe A, Kesten D and Al-Zubi H 2004 The Dead Sea transform: Evidences for a strong fault?; J. Geol. 112 561-575.

Janssen C, Romer R L, Hoffmann-Rothe A, Mingram B, Dulski P, Möller P, Al-Zubi H and DESERT Research Group 2005 The role of fluids in faulting deformation: A case study from the Dead Sea transform (Jordan); Int. J. Earth Sci. 94 243-255.

Kerrich R 1986 Fluid infiltration into fault zones: Chemical, isotopic, and mechanical effects; Pure Appl. Geophys. 124 $225-267$.

Kerrich R and Kyser T K 1994 The geochemsitry and role of fluids in large continental structures: An overview; In: The Mechanical Involvement of Fluids in Faulting, US Geological Survey; Proceedings of Workshop LXIII. Openfile report 94-228:487-501.

Kronenberg A K, Wolf G H and Segall P 1984 Variations in intra-granular water within a strain gradient: FTIR traverse across a ductile shear zone; EOS, Trans. Am. Geophys. Union 651098.

Lottermoser B G 1992 Rare earth elements and hydrothermal ore formation processes; Ore Geology Reviews $\mathbf{7}$ $25-41$.

Manatschal G, Marquer D and Früh-Green G L 2000 Channelized fluid flow and mass transfer along a rift-related detachment fault (Eastern Alps, southeast Switzerland); Geol. Soc. Am. Bull. 112 21-33.

Marquer D 1989 Transfert de matière et déformation des granitoïdes. Aspects méthodologiques; Schweiz Mineralogie. Petrographie. Mittieun 69 15-35.

McCaig A M 1988 Deep fluid circulation in fault zones; Geology 16 867-870.

McCaig A M 1997 The geochemistry of volatile fluid flow in shear zones; In: Deformation-enhanced Fluid Transport in the Earth's Crust and Mantle (ed.) Holness M B, Springer, 333p.

McCaig A M, Wickham S M and Taylor H P Jr 1990 Deep fluid circulation in alpine shear zones, Pyrenees, France: Field and oxygen isotope studies; Contrib. Mineral. Petrol. 106 41-46.

Mitra G 1984 Brittle to ductile transition due to large strains along the White Rock thrust, Wind River Mountains, Wyoming; J. Struct. Geol. 6 51-61.

Mukherjee P K and Gupta P K 2008 Arbitrary scaling in ISOCON method of geochemical mass balance: An evaluation of the graphical approach; Geochem. J. 42 $247-253$.

Nemcok M, Schamel S and Gayer R 2009 Thrustbelts: Structural architecture, thermal regimes and petroleum systems; Cambridge University Press, 551p.

Newman J and Mitra G 1993 Lateral variations in mylonite zone thickness as influences by fluid-rock interactions, Linville Fault, North California, J. Struct. Geol. 15 849-863.

O'Hara K 1988 Fluid flow and volume loss during mylonitization: An origin for phyllonite in an overthrust setting, North Carolina, USA; Tectonophys. 156 21-36.

O'Hara K and Blackburn W H 1989 Volume loss model for trace element enrichment in mylonites; Geology $\mathbf{1 7}$ 524-527.

Pan Y and Fleet M 1995 Mobility of REEs and HFSEs by sea floor hydrothermal activity; Precamb. Res. 74 73-89.

Pêcher A and Scaillet B 1989 La structure du HautHimalaya au Garhwal (Indes); Ecologie Geologie Helvitae 82 655-668.

Potdevin J L and Marquer D 1987 Méthodes de quantification des transferts de matière par les fluides dans les roches métamorphiques; Geodinamica Acta 1 193-206.

Roedder E 1984 Fluid inclusions; Min. Soc. America, Washington, Rev. Mineral., 12 644p.

Rolland Y, Cox S, Boullier A-M, Pennacchioni G and Mancktelow N 2003 Rare earth trace element mobility in mid-crustal shear zones: Insight from Mont Blanc Massif (Western Alps); Earth Planet. Sci. Lett. 214 203-219.

Roy A B and Valdiya K S 1988 Tectonometamorphic evolution of the Great Himalayan Thrust Sheets in Garhwal region, Kumaun Himalaya; J. Geol. Soc. India 32 106-124. Rumble D III and Spear F S 1983 Oxygen-isotope equilibration and permeability enhancement during regional metamorphism; J. Geol. Soc. London 140 619-628.

Sachan H K, Kohn M J, Saxena A and Corrie S L 2010 The Malari Leucogranite, Garhwal Himalaya, northern India: Chemistry, age, and tectonic implications; Geol. Soc. Am. Bull. 122 1865-1876.

Saini N K, Mukherjee P K, Rathi M S and Khanna P P 2000 Evaluation of energy-dispersive $\mathrm{x}$-ray fluorescence 
spectrometry in the rapid analysis of silicate rocks using pressed powder pellets; X-Ray Spectrometry 29(2) 166-172.

Searle M P 1999 Emplacement of Himalayan leucogranites by magma injection along giant sill complexes: Examples from the Cho Oyu, Gyachung Kang and Everest leucogranites (Nepal Himalaya); J. Asian Earth Sci. 17 773-783.

Searle M P and Godin L 2003 The South Tibetan Detachment system and the Manaslu leucogranite: A structural re-interpretation and restoration of the AnnapurnaManaslu Himalaya, Nepal; J. Geol. 111 505-523.

Selverstone J, Morteani G and Staude J M 1991 Fluid channelling during ductile shearing: Transformation of granodiorite into aluminous schist in the Tauern Window, Eastern Alps; J. Metamorph. Geol. 9 419-431.

Shepherd T J, Rankin A H and Alderton D H M 1985 A practical guide to fluid inclusion studies; Blackie, London, $239 \mathrm{p}$.

Sibson R H 1992 Implications of fault-valve behavior for rupture nucleation and recurrence; Tectonophys. 192 283-293.

Simpson C and Wintsch R P 1989 Evidence for deformation induced K-feldspar replacement by myramkite; J. Metamorph. Geol. 7 261-275.

Sinha A K, Hewitt D A and Rimstidt J D 1986 Fluid interaction and element mobility in the development of ultramylonites; Geology 14 883-886.

Stewart M, Holdsworth R E and Strachan R A 2000 Deformation processes and weakening mechanisms within the frictional-viscous transition zone of major crustal-scale faults: Insights from the Great Glen fault zone, Scotland; J. Struct. Geol. 22 543-560.

Streit J E and Cox S F 1998 Fluid infiltration and volume change during mid-crustal mylonitization of Proterozoic granite, King Island, Tasmania; J. Metamorph. Geol. 16 $197-212$.

Touret J L R 2001 Fluids in metamorphic rocks; Lithos 55 $1-26$.

Valdiya K S 1980 Geology of Kumaun Lesser Himalaya; Wadia Institute of Himalayan Geology, Dehra Dun, 291p.

Valdiya K S 1989 Trans-Himadri intracrustal fault and basement upwards south of the Indus-Tsangpo suture zone;
In: Tectonics of the Western Himalaya (eds) Malinconico Jr L L and Lillie R J, Geol. Soc. Am. Spec. Paper 232 153-168.

Van den Kerkhof A M and Hein U F 2001 Fluid inclusion petrography; Lithos 55 27-47.

Vidal O, Parra T and Trotet F 2001 A thermodynamic model for $\mathrm{Fe}-\mathrm{Mg}$ aluminous chlorite using data from phase equilibrium experiments and natural politic assemblages in the 100-600 C, 1-25 kbar P-T range; Am. J. Sci. 301 557-592.

Vidal O, Parra T and Vieillard P 2005 Thermodynamic properties of the Tscherrmak solid solution in Fechlorites: Application to natural examples and possible role of oxidation; Am. Mineral. 90 359-370.

Vityk M O, Bodnar R J and Dudok I V 1995 Natural and synthetic re-equilibration textures of fluid inclusions in quartz (Marmarosh Diamonds): Evidence for refilling under conditions of compressive loading; European J. Mineral. 7 1071-1087.

Vityk M O, Bodnar R J and Dudok I V 1996 Hydrocarbon inclusions in Marmarosh Diamonds: Evidence for tectonic history of the folded Carpathians?; Tectonophys. 255 163-174.

Vocke R D, Hanson G N and Grunenfelder M 1987 Rare earth element mobility in the Roffna gneiss, Switzerland; Contrib. Mineral. Petrol. 95 145-154.

Wayne D M and Sinha A K 1988 Physical and chemical response of zircons to deformation; Contrib. Mineral. Petrol. 98 109-121.

Wayne D M and Sinha A K 1992 Stability of zircon, U-Pb systematics in a greenschist-grade mylonite: An example from the Rockfish valley fault zone, central Verginia, USA; J. Geol. 100 593-603.

White S H, Burrows S E, Carreras J, Shaw N D and Humphreys F J 1980 On mylonites in ductile shear zones; J. Struct. Geol. 2 175-187.

Wintsch R P, Christoffersen R and Kronenberg A K 1995 Fluid-rock reaction weakening of fault zones; J. Geophys. Res. 100(B7), 13,021-13,032.

Zhang Y and Frantz J D 1987 Determination of the homogenization temperatures and densities of supercritical fluids in the system $\mathrm{NaCl}-\mathrm{KCl}-\mathrm{CaCl}_{2}-\mathrm{H}_{2} \mathrm{O}$ using synthetic fluid inclusions; Chem. Geol. 64 335-350. 